\title{
Japanese Perspective on Korean Reunification: An Analysis of Interrelations between Social Identity and Power*
}

\author{
KARINA KOROSTELINA** AND YUJI UESUGI ${ }^{* * *}$
}

\begin{abstract}
The paper explores how experts in Japan assess and understand the process and consequences of the unification of the Republic of Korea (South Korea) and the Democratic People's Republic of Korea (North Korea). Based on the theoretical framework of interrelations between social identity and power, this paper asks how Japanese experts frame the process of Korean unification and evaluate its impact on Japan. The data was collected in Tokyo, Japan, through 37 semi-structured and focus group interviews, then examining these interviews using phenomenological and critical discourse analysis. Analysis of data reveals the existence of four competing narratives rooted in the complex relations between meaning of identity, concepts of power, and Japanese policies toward the unification process. The paper expands the description of two narratives currently present in the existing literature, (1) threat and (2) peace, and introduces two new narratives, (3) democratic processes and (4) restorative justice. The final discussion explores how three groups of factors, (1) regional dynamics, (2) domestic policy, and (3) possible models of unification, influence the prevalence of a particular narrative as well as resulting policies of Japan toward Korean unification.
\end{abstract}

Keywords: Japan, Korea, Reunification, Social Identity, Power

* This work was supported by the POSCO Fellowship Program at the East-West Center, the U.S., the Institute for Advanced Studies at the Waseda University, Japan, and the MEXT KAKENHI Grant Number JP17H06336.

** Professor, George Mason University, VA, USA, E-mail: ckoroste@gmu.edu;

*** Professor, Waseda University, Japan; E-mail: uesugi@waseda.jp;

DOI: $10.16934 /$ isr.21.1.202006.47 


\section{INTRODUCTION}

Japan sees the Korean peninsula as a crucial region for its own security, stability, and prosperity, and thus pays attention to the processes of peace and unification of Korea. Through its "Policies for the Two Koreas" adopted in the early 1990s and the "Guideline for the U.S.-Japan Defense Cooperation" of 2015, Japan secured involvement in issues related to Korean unification. Japan actively participates in international discussions and shows willingness to be involved in deeper unification processes. As the Korean reunification unfolds, it is important to explore how experts in Japan assess and understand processes and consequences of the unification of the Republic of Korea (South Korea) and the Democratic People's Republic of Korea (North Korea). The paper asks how Japanese experts (a) see the process of Korean unification and (b) evaluate the impact of unification on Japan. Because the Japanese assessment of unification is represented by multiple competing narratives, understanding the roots and foundations of these narratives, as well as factors promoting or impeding the prevalence of specific narratives, is critical.

The theoretical foundations of the paper arrive from conceptual frameworks of social identity and power. The paper posits that the perceptions of unification are deeply rooted in complex interrelations between meanings of ingroup and outgroup identities and four major concepts of power. Perceptions also depend on dynamics of international relations within the region as well as on the model of unification experts see as more plausible or favorable. Understanding these evaluative processes can help assess and predict reactions and policy-making in Japan regarding the unification of South and North Koreas. More specifically, the paper seeks to (a) understand the Japanese national strategy toward the unified Korea and (b) addresses how unification processes may impact international relations within the region.

\section{THEORETICAL FOUNDATIONS}

The classic definition of power is "the ability of one party to influence the behavior of the other party and reduce the ability of the other party to achieve its objectives" (Harper 1953; Kelman 1958; Cartwright 1959). A powerful agent can posit a threat to others by producing conditions or feelings of their inadequacy to deal with a current situation to satisfy their needs. The degree of threat depends upon the degree of power, which can be exercised within the system and can be increased in stressful or ambiguous situations. With this approach, power involves dependence and coercion against people's will, changing people's will and beliefs through norms and social institutions (Moscovici 1976). Thus, a 
significant body of research in international relations concentrates on the quotative characteristics of power, including balance of power and threat, rooted in such characteristics as the size of national economies, gross domestic product (GDP) growth rates, and military capabilities.

However, many scholars also stress understanding power as a relational quality rather than a 'possession' of an actor, and emphasize power depends on the obedience and cooperation of others and their contributions to the established system (Dahl et al. 1957). In these studies, power is rooted the actors' own appraisals and relationships within a political context. Similarly, actions are understood as arriving from these interpretations and assessments of relations. This approach underlines the existing variations of power and its meaning employed by different actors. Such variations in the meaning of power depend on conceptual frameworks, systems of knowledge, and discursive practices (Guzzini 2000; Barrett 2002; Mann 2012). To analyze the variations of meaning, scholars have produced several taxonomies, including Nye's (2002) concepts of "soft power" and "hard power", Gruber's (2000) concept of "go-it-alone power," French and Raven's (1959) concepts of "reward power, coercive power, legitimate power, referent power, and expert power," and Galam and Moscovici's (1995) taxonomy of "institutional power" as a power to dominate the group, "generative power" as a group's capacity for mobilizing skills and multiplying resources, and "ecological power" that mobilizes and directs activities toward the outside world. Barnett and Duvall (2005) proposed a fourfold taxonomy including compulsory, institutional, structural, and productive power. This taxonomy is rooted in the distinction between "power over" (Weber 1978) and "power to" (Arendt 1970; Barnett and Duvall; 2005) as well as between direct and immediate social relations of power. Compulsory power represents a clear case of coercive power and direct control over another party, while institutional power requires involvement of the "third party," such as an institution or a law. Both structural and productive power emphasize how actors are defined through their relations.

In addition to the above-mentioned Western-centric conceptions of power, Japanese conceptions of power are employed in this paper. Japanese scholars such as Masamichi Royama, Akira Osawa and Hikomatsu Kamikawa endeavored to establish a Japanese perspective of International Relations distinct from the Western mainstream (Ikeda 2008). Unlike European colonial powers that had their colonies far from the metropole, Imperial Japan expanded its sphere into its geographical neighborhoods such as Taiwan, Korea, and Manchuria, requiring a conceptualization of power, not in a hierarchical manner (power over), but as effects within a community to be exercised centripetally. While such an attempt failed in practices of the Greater East Asia Co-Prosperity Sphere, also conceived to give emancipatory power to Asian nations from the European world and its 
rule (Ikeda 2008), power was theorized to be based on co-prosperity (power with) and would give legitimacy to Imperial Japan to lead others (power through).

While these conceptions of power are not entirely unique to contributions made by Japanese scholars, the following four forms of power presented in scholarly discourses are used in this paper. Power over rests on the will of its users to enforce others within a social relations framework (Weber 1978) as well as the imposition of power by social structures (Foucault 1981). Power to is defined as an independent form of power, constituting an important aspect of social life (Arendt 1970; Barnett and Duvall 2005), as a productive power giving people the initial possibility to act and to be empowered, developing resistance to existing structures of power or alternative symbolic systems (Bourdieu 1972; Foucault 1981; Royama 1928). Power with as an ability to work jointly and in solidarity (Allen 1999; Kamikawa 1927/1966) rests on interactions within a society-people speaking and acting "in concert" (Arendt 1970). Power through is another legitimate power resting on internalized values and the acceptance that a leader has legitimate rights to influence people who have an obligation to accept this influence (Sharp 1973; Osawa 1931); this includes persuasion as power to convince people of the rightness of a particular order and shared belief in validity of a ruler (Turner 2005).

This framework of four forms of power reflects an understanding of power relations as rooted in conceptions of social identity. Competing narratives of relations are based not only on the meanings of groups' identities but also on the power struggles within the existing order. The formation of a shared social identity is a necessary precursor to social influence strategies: "Group identity unifies and empowers people by giving them a common self-interest and vantage point. It produces influence which enables a group to act as a unified, coordinated, organized body" (Turner 2005, 13). Power emerges from human social relationships, from the capacity of people to organize themselves into social groups, institutions, and societies. However, the social group is also an outcome, rather than simply a precondition of influence (Festinger 1953).

Complex interrelations between meanings of social identity and concepts of power congeal in coherent narratives about intergroup relations. Competing, contrasting, and sometimes overlapping, these narratives create a complex landscape of views on the past, current, and future interrelations between ingroup and outgroups. Depending on multiple internal and external factors, these competing narratives remain relatively stable within a particular political and social order. 


\section{PERCEPTIONS OF THE UNIFICATION OF KOREA IN THE LITERATURE}

Views of Japan on the unification of Korea were explored by several scholars who stress pacific powers may have a greater sense of uncertainty toward a unified Korea than toward a divided Korea (Lee 2001). While unification has significant importance for Japan, it has very limited tools because of historical legacy and post-war polity, thus Japan has to be more reactive and adaptive to changes on the Korean peninsula (Armacost and Pyle 2001). According to these authors, the Japanese Government appears disoriented in the post-Cold War context that limits Japan's ability to formulate international policies in rapidly changing regional relations. Relations between Japanese and Koreans are also complicated by the history of Japanese colonization and unfinished process of reconciliation influenced by mutual mistrust. Some scholars stress Japanese emotional ambivalence towards the two Koreas as well as the divide within Koreans living in Japan (Nilsson-Wright 2019). These problems of relations limit the repertoire of Japanese policies and responses toward the unification of Koreas. Major security imperatives include a nuclear weapons-free unified Korea and its friendliness towards Japan. Improving relationships between South Korea and Japan can be an assurance for such developments, as well as a foundation for cooperation in the region.

A majority of scholars assess Japanese position in the framework of security studies. Japan has an enormous stake and security concerns about the unification of Koreas, seeing North Korea as an immoral state expressing strong anti-Japanese sentiments and abducts Japanese citizens (Hwang 2010; Arrington 2018). According to these scholars, a unified Korea with nuclear weapons may force Japan to develop their own nuclear weapons. Other scholars discuss the possibility of the alliance between the unified Korea and China as a serious threat to Japan's position in the region (Bae et al. 2014). Several scholars underlined the role of U.S. foreign policy toward East Asia in the perception of security issues related to North Korea (Park 1988; Samuels 2006; Michishita 2014), impact of diplomatic relations and leadership (Sakaedani 2005; Kim 2014), and centripetal and centrifugal force ( $\mathrm{Ku} 2016)$.

However, other scholars underlined that Japan prefers a peaceful unification process and has concerns about possible war or sudden collapse of North Korea (Kim and Park 2012). These scholars stress the division of Korea should be recognized among the Japanese public as a result of colonization and thus Japan's responsibility. Scholars suggest Japan prefers a dialogue and security arrangement between multiple states as a way towards unification of Korea (Tanaka 2006). The gradual democratization of North Korea and economic and humanitarian assistance by Japan is considered by Japanese experts to be the 
best-case scenario for unification (Sakamoto 2010). This can also reduce the unpredictability and threat of North Korea (Bae et al. 2014).

Another group of scholars reviewed Japanese positions based on the specificity of their national identity. Some studies emphasize the hierarchical construction of the Japanese "Self" versus the inferior Korean "Other" across the national boundary (Tamaki 2010; Guillaume 2011; Hagstrom 2016). A hierarchical worldview with emphasizing Japanese superiority and uniqueness influences Japan's relations with other Asian neighbors. These neighbors, including South Korea, are perceived either as positing a threat to the Japanese identity, and thus, they should be controlled, or as subordinate nations to be exploited. Variations in Japanese national identity and perceptions of neighboring countries are represented in four schools of Japanese political thoughts: (1) Statism, (2) Ethnic Nationalism, (3) Internationalism, and (4) Pacifism (Rozman 2001). Some scholars discuss in detail how national identity in Japan impacts perceptions of South Korea; however, these scholars do not specifically address the issue of unification of Koreas (Glosserman and Snyder 2015).

To address this gap in the literature, this study brings (a) a new theoretical perspective of the interrelations between meanings of social identity and concepts of power into (b) an analysis of the Japanese perspective on the unification of Koreas and (c) discusses the impact of competing narratives on policy-making in Japan.

\section{METHODOLOGY}

\section{Data collection}

Data for this study was collected in the capital of Japan, Tokyo, during the summer 2018 and included face-to-face, semi-structured interviews and focus groups interviews. Each interview included six questions developed to explore the formation and functioning of interpretative frames and concepts of power, including construction of ingroup and outgroup identities and meanings in the process of framing and power dynamics assessment (see Appendix). For this purpose, we concentrated on the assessment of the reunification of Korea and implications of this process for Japan, as well as possible problems connected with the reunification. Other topics included (1) the importance of history and memory for national identity in Japan, (2) the connection between interpretations of history and current conflicts between South Korea and Japan, and (3) an assessment of the reconciliation process between South Korea and Japan, including official apologies made by successive Japanese governments. Each individual interview or focus group lasted between one and two-and-a-half hours. 
The sample includes two sets of interviews with a total number of 37 respondents. Results of both personal interviews and focus group interviews were merged in this analysis. The sampling method comprised of snowballing with several entry points to ensure a diversity of views and attitudes. The final sample for individual interviews included 20 respondents, including 16 academics (historians, political scientists, sociologists, international relation scholars who work as university professors or scholars in think-tanks), 2 representatives of non-governmental organizations (including peacebuilding and youth organizations), and 2 doctoral students working on projects in the field of foreign affairs. 6 of our respondents are actively involved or were involved in advising and policymaking toward the Korean peninsula. 6 of the interviewees were female, and 14 were male; the age of the respondents ranged from 28 to 70 (median is approximately 45 years old). Interviews were conducted primarily in English, though an interpreter assisted in one interview. Given the majority of the interviewees write and communicate in English in professional and international settings, the English proficiency of most of the interviewees was high. The final sample for focus group interviews included 17 respondents, including BA and MA students from Waseda University and International Christian University in Tokyo. 10 interviewees were female and 7 were male, and age ranged from 19 to 25. Interviews were conducted in English. Given all of them write and communicate in English in academic settings, English proficiency was high. The interview protocol was approved by the Mason's Institutional Research Board (Project Number: 1245830-1). According to the protocol, data in this study is confidential and no name could be mentioned in the analysis or presentation of the results.

\section{Data Analysis}

To analyze the interview data, we employed a combination of phenomenological analysis and critical discourse analysis (Quinn 2002; Robson 2011). These methods of data analysis enable researchers to understand meanings of identity and concepts of power experts use to understand past events and experiences in the context of today's discourse. Several stages comprise a phenomenological analysis. First, several themes were identified to manage large data clusters without losing the deep meaning of received information or the focus of the research questions. We formed specific clusters by merging similar or related themes and making a summary table of the structured themes. The analysis carried out on each individual interview has contributed to the generation of common, general themes for all or most of the interviews. The themes then were combined into four clusters representing four concepts of power and the related meaning of identity. Second, within each cluster, we identified factors defining 
the perceptions of possible reunification of two Koreas. Critical discourse analysis helped examine meaning of identity in its broad social and historical context and explore the ways in which power dynamics are produced and reproduced by dominant or hegemonic discourses through the construction of meaning, knowledge, and ideology.

\section{OBJECTIVITY AND VALIDITY}

Multiple approaches have been taken to establish research objectivity. The credibility of the research findings was ensured through the standardization of the data collection procedures and implementation of coding to organize the data. Procedural validity included note-taking procedures, required recording of each response to the question being asked, consistent wording and sequencing of each question for all participants. Reflexivity was ensured through continuous scrutinization of the research process and mindfulness about the role of researchers, as well as biases and positions on issues. As a routine, the authors documented these reflections systematically. The triangulation of the interview results with the existing data and results of surveys conducted by other organizations was used to increase the research objectivity.

The authors acknowledge the limitations of the research methodology that is based on the purposive and snowballing sample with the size of 37 respondents. The results can only be connected with the selected sample and do not represent the opinion of all Japanese experts. Thus, the results of this study may represent only some views on unification of Korea.

\section{RESULTS}

The analysis of the collected data reveals the existence of the four narratives, as shown in Table 1, which are resulted from the relations amongst the meaning of identity, concepts of power, and Japanese policies toward the reunification process.

TABLE 1

\begin{tabular}{cccc}
\hline Narrative & $\begin{array}{c}\text { Meaning of ingroup and outgroup } \\
\text { identities }\end{array}$ & $\begin{array}{c}\text { Concept of } \\
\text { power }\end{array}$ & Possible policies \\
\hline $\begin{array}{c}\text { Reunification of Korea } \\
\text { will create a threat for } \\
\text { Japan }\end{array}$ & $\begin{array}{c}\text { South and North Koreas are } \\
\text { adversaries for Japan }\end{array}$ & $\begin{array}{c}\text { Coercive } \\
\text { power } \\
\text { (power over) }\end{array}$ & $\begin{array}{c}\text { Threats, coercion, } \\
\text { military development }\end{array}$ \\
\hline $\begin{array}{c}\text { Reunification of Korea } \\
\text { will promote reconciliation } \\
\text { and democratic } \\
\text { processes in Japan }\end{array}$ & $\begin{array}{c}\text { Japan is responsible for colonizing } \\
\text { and mobilizing Koreans for the war } \\
\text { as well as for the divisions of Korea }\end{array}$ & $\begin{array}{c}\text { Legitimate } \\
\text { power }\end{array}$ & $\begin{array}{c}\text { Reconciliation efforts, } \\
\text { democragh) }\end{array}$ \\
\hline
\end{tabular}




\begin{tabular}{|c|c|c|c|}
\hline Narrative & $\begin{array}{l}\text { Meaning of ingroup and outgroup } \\
\text { identities }\end{array}$ & $\begin{array}{l}\text { Concept of } \\
\text { power }\end{array}$ & Possible policies \\
\hline $\begin{array}{l}\text { Reunification of Korea } \\
\text { will result in } \\
\text { cooperative policies of } \\
\text { restorative justice }\end{array}$ & $\begin{array}{l}\text { Both Japan and Korea are } \\
\text { responsible for suffering of victims, } \\
\text { including victims of Japanese } \\
\text { occupation policies in Korea and } \\
\text { Japanese abductees by North Korea }\end{array}$ & $\begin{array}{l}\text { Cooperative, } \\
\text { power "in } \\
\text { concert" } \\
\text { (power with) }\end{array}$ & $\begin{array}{c}\text { Retribution, cooperation } \\
\text { between legal authorities, } \\
\text { demands for return of } \\
\text { Japanese abductees }\end{array}$ \\
\hline $\begin{array}{l}\text { Reunification of Korea } \\
\text { will promote peace in } \\
\text { the region }\end{array}$ & $\begin{array}{c}\text { Japan as a country with a strong } \\
\text { value of peace }\end{array}$ & $\begin{array}{l}\text { Empowerment } \\
\text { and change of } \\
\text { structures } \\
\text { (power to) }\end{array}$ & $\begin{array}{l}\text { Cooperation between } \\
\text { governments and civil } \\
\text { society in reunification } \\
\text { and peacebuilding efforts } \\
\text { in the region }\end{array}$ \\
\hline
\end{tabular}

\section{Reunification of Korea will create a threat for Japan}

This narrative, supported by 14 respondents (38\% of the sample), highlights the threat to Japan that resulting from a unified Korea. These respondents emphasize both South Korea and North Korea will reinforce each other's negative attitudes toward Japan, resulting in increasing tensions between the united Korea and Japan. As one respondent states, "When two Koreas will have good relations, it will harm (their) relations with Japan." Another respondent echoes, "South Korea and North Korea are anti-Japanese nations thus the (re)unification (of the two) can be a threat to Japan. Reunification of two Koreas can allow them to unite against Japan." These respondents believe more hostilities and negative perceptions of Japan will likely be an outcome of the reunification process. As one respondent explains, "Nationalism in Korea will grow, so the united Korea will be more nationalistic and anti-Japanese."

This narrative rests on interrelations of perceptions of South Korea and North Korea as adversaries to Japan and the concept of coercive power (power over). These respondents see South Korea as a rival state with a strong nationalism arriving from historical narratives about Japanese wrongdoings and negative stereotypes about Japan promoted by the South Korean Government. Respondents describe compulsory education in South Korea as anti-Japanese, emphasizing adverse attitudes toward Japan. As one respondent states, "Education in South Korea plays a very important and negative role. Many people in South Korea, including students, are always reminded what Japan did during the era of colonization. They see themselves as victims of Japan's aggression." Another respondent echoes, "In South Korea, they are told that they are victims, and it is profound in their history education and national narratives. It shapes their perception of WWII." Another channel of forming negative attitudes toward Japan and nationalistic attitudes toward history between the two countries is media and public diplomacy in South Korea, which are portraying Japan in a very negative light. As one respondent states, "In South Korea, there is much more awareness about history. They employ very good public diplomacy and 
public opinion making based on history." Finally, 8 respondents highlight the role of civil society to promote negative attitudes toward Japan. As one respondent explains, "They redefine violence and colonization as human right issues: for them de-colonization and democratization are connected." Another respondent stresses "Civic movement brought up the comfort women issue and media contributed to rising tensions." As a result, South Korean public have negative collective emotions, strong nationalism, and negative perceptions of Japan that are persistent and difficult to challenge.

According to respondents, South Korea's emphasis on the history of war aims at increasing the salience of their national identity. Focusing on negative history and victimhood, South Korean politicians boost the feelings of national unity among public. As one respondent states, "Victimhood and negative attitudes towards Japan unites people in South Korea. It is hard to become a politician there without catering to the public. It is a self-trap there." 10 respondents also stress the employment of historical narratives in increasing national self-esteem and pride. Respondents discuss the issue of Takeshima/ Dokdo island as an affirmative symbol of the independence war and positive national identity. As one respondent explains, "South Koreans did not get their independence as a result of their war efforts, it was brought by the U.S. victory (over Imperial Japan). On the other hand, the island was taken forcefully from Japan by South Korea's unilateral action, thus the island is a representative of the Korean victory." Another respondent echoes, "The fight for the island is a representation of their national pride."

Similarly, these respondents describe North Korea as an adversary state to Japan. Acknowledging limited information about North Korean regime, these respondents emphasize hostilities and aggression from North Korea. As one respondent explains, "It is a strange country because of its political regime." Another respondent also emphasizes the doubts, "We do not know how North Korea represent history. All we know is that they abduct people, so the reunification could bring more problems to Japan."

Such narratives are deeply rooted in the concept of power as coercion (power over). These respondents concentrate on the power competition and the ability of South Korea to influence the position and image of Japan on the world arena. They also see the unified Korea as an agent that can posit a threat to Japan and create a very hostile environment in the region. 13 respondents emphasize South Korea employs historical narratives to increase its power in the international arena. As one respondent states, "South Korean Government is using this conflict to increase its power. They manipulate power and history to unite its country." Another respondent describes, "For South Korea, the memory of Japanese occupation dominates. South Korea always tries to bring this issue, and Japan think they are using it to gain more power and influence." Yet, another respondent 
echoes, "South Korea is deliberately using the issues of comfort women and the disputed island for political purposes, bringing them to the international level and harming the image of Japan. It succeeds in undermining Japanese position by using an idea of victimhood. They use all available means." They also believe that South Korea deliberately employs the historical narrative of colonization to get an upper hand position in negotiations with Japan.

11 respondents believe a unified Korea will increase Korea's power in the region, providing stronger control over disputed island, and intensify its ability to harm the position of Japan in the world. As one respondent describes, "Japan and South Korea should be allies, but if North Korea, with its positive relations with China, joins South Korea, it will be very damaging to Japan." 9 respondents discuss a nuclear united Korea as the most threatening outcome of the reunification process. Respondents do not believe North Korea would give up its nuclear weapons. As one respondent explains, "Kim (Jong-Un) denies the possibility of giving up his nuclear weapons. North Korea has successfully developed nuclear weapons to protect itself and get a world-wide attention. Kim would never give them up." Another respondent states, "Seventy million people with nuclear weapons and good economy can be a strategic threat to Japan." Another respondent seconds, "We see North Korea as more threat than South Korea. I hope that the threat will be reduced, and de-nuclearization will happen (in North Korea)."

This narrative prescribes the development of multiple defensive measures by Japan to protect its position in the region and its image in international relations. Respondents see a peaceful and nuclear-weapons-free state as the most essential requirement for the unified Korea; however, they do not believe any substantial or credible information is available to support this premise. Instead, respondents anticipate a unified Korea will be militaristic and anti-Japanese. Thus, according to respondents, the process of unification requires developing policies aiming at protecting Japan's interests and security. In addition, some respondents discuss possible demands for compensations and retributions that North Korea could make. One respondent states, "North Korea wants to receive money as we did not pay because we did not have diplomatic relations with them. Now North Korea can claim payments and compensations." These respondents see this probable demand for reparations to North Korea as a significant threat to Japanese economy and political standing and underline the importance of protecting Japanese interests and positions. 


\section{Reunification of Korea will promote reconciliation and democratic processes in Japan}

The next narrative, supported by 9 respondents ( $24 \%$ of the sample) centers on the opportunity for Japan to fill its moral responsibility for past colonial policies and for the division of Korea. These respondents stress Japan's responsibility for the creation of divided Koreas and believe unification opens the door for Japan to address this issue. As one respondent explains, "Division of Koreas in 1948 was a tragedy for everyone. It has led to a civil war. In 1950s, the U.S. needed an ally to fight against North Korea and thus it built cooperation with Japan. This divide was a mistake." 5 respondents compare the results of the World War II in Europe and Northeast Asia, stressing the aggressor stateGermany - has become divided by the victorious powers, but Korea, a victim state, has become a subject for ideological and territorial partition. They discuss, because Japan initiated the war with China and the U.S., Japan played an important role in the division of Korea. As one respondent discusses, "As Japan did not surrender in time, it should take responsibility for the division of Korea and help the (re)unification process." According to 6 respondents, the Korean people believe Japan supported the separation of the Koreas and profited from the Korean war. As one respondent states, "People in both Koreas hold Japan responsible for the division and violence between Koreas."

This narrative is based on the ingroup identity of Japan as a former aggressor that has a moral responsibility for completing reconciliation between Japan and two Koreas, and for supporting the reunification of Korea. These respondents discuss the Japanese public, especially among the older generation, regret and condemn suppressive actions of Japan in Korea. These respondents have strong pacifistic attitudes, have a deep feeling of guilt, and stress the importance of apology and compensation for Japanese colonial policies in Korea. As one respondent states, "People feel very sorry for what Japan did to Korea, for colonialism and aggression, and believe that Japan needs to deal with it." As another respondent verifies, "Japanese people feel guilty and nervous in relations with South Korea."

However, 5 respondents discuss the change in the attitudes among the new generation arriving from the recent changes in history education. They argue young Japanese have very limited knowledge about Japan's colonial policies in Korea. As one respondent clarifies, "In Japan, people do not know what really happened during the occupation, and thus, they are frustrated by South Korean Government's attempt to bring an accusation again and again. Japanese only know the fact that Japanese colonization accelerated the modernization process of South Korea." 4 respondents also discuss the prevalence of beliefs among Japanese public about the positive impact of the occupation and Japan's 
colonization policies in Korea, while negative facts about the colonial history in Japan are often denied or distorted. Common concerns include the portrayal of forced laborers, comfort women, and general descriptions of colonization in history textbooks used in a compulsory public education in Japan. These respondents also discuss it is hard for the Japanese people to face this contentious past, so that many people turn to oblivion. As one respondent states, "It is hard to apologize and rescue history at the same time. It is a symbolic phenomenon that shows how deep historic amnesia progresses in Japan." Another respondent emphasizes, "In Japan, people consider history belong to the past and do not want to return to it again and again."

This narrative is rooted in the conception of legitimate power (power through) that stresses that the values of moral responsibility and a revisionist approach for history gives Japan legitimate rights to assist in and influence the process of unification of Korea. 8 respondents discuss addressing the issue of Japan's responsibility for the colonization of Korea and its partition will convince powers in the region in the rightness of Japan's participation in the reunification process and its validity as a regional leader. These respondents also see the unification of Korea as an opportunity for Japan to finally make things right and, thus, to increase its legitimate power through improving the relationships between Japan and Korea.

This narrative prescribes policies promoting a deep historic analysis of Japanese policies and actions during the colonization of Korea. As one respondent states, "Memory of the war is very important. All political and economic problems are discussed in terms of Japan's war responsibility in the WWII." Similarly, another respondent argues, "We need to start reviewing what we have done in the past. Both glories and mistakes are important for Japanese history. Japan has to face all of it." These respondents emphasize history textbooks should adequately describe the history of Japan's colonial occupation and the role of Japan in the division of Korea. Similarly, these respondents state the Japanese Government should include history-related issues in public policy and support both Koreas. According to these individuals, such policies will help Japan to play a leading role in the reunification and de-nuclearization of Korea.

\section{Reunification of Korea will result in cooperative policies of restorative justice}

The next narrative, supported by 8 respondents ( $21 \%$ of the sample) focuses on collective processes of restorative justice between Japan and North and South Korea. This view posits the reunification process is a possibility for dealing with the legacy of colonialism. This view also stresses the importance of reciprocity in restorative justice, including (a) Japanese actions of compensating victims of Japanese colonial policies in Korea, (b) North Korean actions of 
returning of Japanese abductees, and (c) South Korean actions to address its responsibility for violence against its citizens. First, 7 respondents acknowledge the need to compensate victims in North Korea. As one respondent stresses, "After the (re)unification, Japan needs to negotiate compensation with North Korea." Another respondent echoes, "We need to discuss compensation with North Korea, as we have never done it." Second, as a prerequisite, these respondents state the return of all Japanese abductees by North Korea. As one respondent stresses, "Japan should insist on returning the victims of abduction, as it is an issue of human rights." They see the reunification as an open door for the resolution of the abduction issue. As one respondent discusses, "This reunification of Korea is a hope for their (victims of abduction) return." Third, according to these respondents, South Korea can adopt the North Korean approach to dealing with perpetrators of violence and war. As one respondent explains, "North Korea resolved issue of the past, punished or expelled all collaborators with Japan while in South Korea many of the former perpetrators' children are still in power." As another respondent discusses, "South Korea did not deal with colonialism, have difficulties to face it, and it affects its relations with Japan. The approach that North Korea used toward the history may help to finish conversations about the war." Thus, describing Japan, South Korea, and North Korea as both victims and perpetrators, the narrative states unification will create an opportunity to restore justice and collaboratively address the wrongdoings and crimes of all involved parties.

This narrative rests on the ingroup identity of Japan as both responsible for colonization and also victim of abductions by North Korea and unfair treatment by South Korea, as well as on the outgroup identity of South Korea as a state that uses history for personal gain and the outgroup identity of North Korea as an aggressor state. This narrative is also based on the concept of power as cooperation (power with).

Six respondents describe the Japanese Government's apology as incomplete or ingenuine, with contradictory statements by government officials and politicians. As one respondent states, "Japan issued an apology for only few things, it does not cover everything." Another respondent echoes, "Japan never did enough for reconciliation, some politicians ignored or denied responsibility." According to these respondents, those conservative politicians believe that Japan did nothing wrong and condemn any sincere apology.

8 respondents also emphasize the responsibility of both North Korean and South Korean Governments for continuous tensions. These respondents stress the aggressive actions of North Korea have not been completely addressed. As one respondent notes, "We still need to remember abductions, Japanese citizens were not returned." They also discuss the collaboration of Korean political and business leaders with the Japanese Imperial Government and their participation in 
the implementation of colonization policies. According to them, South Korea has never acknowledged and addressed these issues appropriately. Thus, the issue of the human rights of women and forced laborers should be considered as priority by both Japanese and South Korean Governments.

This narrative rests on a concept of power as cooperation (power with), stressing the unification process can promote regional collaboration in restorative justice and thus increase an ability of Japan and two Koreas to work jointly and address major problems in solidarity. All 8 respondents stress, in cooperation with Japan, a unified Korea would return Japanese abductees and thus restore justice in the region. Similarly, "in concert" with Japan and North Korea, South Korean Government and civil society would finally address the issues of the contentious past and accept responsibility for autocracies and violent polices toward the Korean people.

This narrative prescribes comprehensive negotiations between Japan and two Koreas to address wrongdoings of Japanese Imperial Government and its Korean collaborators. These respondents stress, while Japan should compensate the victims and sincerely apologize to them, South Korea should acknowledge the role of Korean elite in Japan's colonization of Korea. They also stress possible reparations to North Korea should depend on the return of abducted Japanese citizens and see the economic development of North Korea as a possibility for Japan to make investments and profit financially. According to these respondents, the process of compensation can be an excellent opportunity for Japan to make economic contributions and profit out of reconstruction and development businesses. They believe combined efforts of all three countries in the process of restorative justice and compensation for victims can create a solid foundation for justice and security in the region. They also discuss cooperation between the new united Korea and Japan will help Japan to stand against Russia and China. As one respondent states, "It is very important to improve relations with Korea, as Japan is a small country. We face the same threats and need to unite with each other to face the rise of China and Russia."

\section{Reunification of Korea will promote peace in the region}

The next narrative, supported by 6 respondents (16\% of the sample) describes how the unification can promote resolutions of conflicts and peacebuilding in the region. As one respondent states, "The (re)unification will create peace. I am very positive about it." These respondents believe unification is the endpoint for the World War II era and the beginning of new relationships of eternal peace. Reunification could improve relations between two Koreas and their attitudes toward Japan. As one respondent states, "Now Koreas are divided as a nation in conflict. Their (re)unification will bring peace and improve 
relations in the region in general." Another respondent discusses, "Koreas can improve relations with Japan when they both become more open." 4 respondents state that better relations between Koreas will reduce security concerns for Japan regarding conflict between South and North Koreas and escalation of violence in the region. One respondent explains, "Japanese people have believed that they need to protect themselves from nuclear weapons in North Korea. However, if peace is achieved, then we can start a positive communication with North Koreans." Finally, 3 respondents believe reunification will increase understandings of Korea among Japanese public as more information about North Korea becomes available.

This narrative is based on an ingroup identity of Japan as a nonviolent country with a strong value of peace and the concept of productive power (power to). 5 respondents state Japanese national identity lacks nationalistic feelings and aggressive attitudes. They state nationalism is avoided in Japan. Instead, public education promotes a moral learning with an emphasis on values and social norms of the society and foundations of democratic social order. As one respondent states, "There is no common meaning of identity and views on history in Japan. Education avoids emphasizing national identity, nationalism, and patriotisms. Not a lot of respect for national symbols because they are connected to war." 4 respondents discuss, together with the decrease in the salience of Japanese national identity, the history of occupation and war has produced strong motivations for amity and aspirations for peace among Japanese public. As one respondent stresses, "Being peaceful is the most important value for Japanese identity." Another respondent explains, "History of WWII made us very careful and peaceful, very conscious about how easily you can become powerful and then fail. So, it is very important to be careful, not to be nationalistic."

This narrative is rooted in a concept of productive power giving people initial possibility to act and to be empowered. All 6 respondents see the process of unification as an inspiring and empowering process to change existing structure of conflict and symbolic systems of divergence in the region and to build lasting peace. These processes include the return of Japanese abductees by North Korea, compensation of victims, reconciliation, and effective cooperation between all countries in the region.

This narrative prescribes the promotion of the values of peace. These respondents state Japan, as a peaceful country, should inspire and empower two Koreas to develop harmony and reconciliation in the region. They believe Japan should become a leader, placing the unification of Koreas within a context of peacebuilding. According to these respondents, Japan's policies should aim at improving relations between Japan and the united Korea as creating a pathway towards peace in the wider region. 


\section{DISCUSSION}

In her previous work, Korostelina (2013) argued interrelations between social identity and power are constituted by two opposite but tangled processes: national identity defines, and is defined by, systems of power thus producing (1) an embedment of the concept of power into meanings of identity and (2) defining power by the meaning of national identity. In other words, specific meanings of power and power relations between nations are incorporated as a core of a particular national identity, determining, shaping, and giving meaning to national identity. At the same time, the meaning of national identity determines, shapes, and gives meaning to the legitimation of power and design of the ideal social order. Four major narratives about the unification of Korea are centered around this complex interrelation.

Japan considers international cooperation in the region to be "strategic," allowing it to favor own national interests (Young et al. 2012). As this study shows, Japanese reactions to changes related to the unification process are rooted in the meaning of ingroup and outgroup identity and prevailing concepts of power. These reactions vary from emphasizing threat and moving further away from restrictions on its military forces to leading positive democratic changes through regional cooperation. Three sets of factors can promote or impede the prevalence of a specific narrative: (1) regional dynamics, (2) domestic policy, and (3) models of unification.

First, as many experts noted, the Japanese position on Korean unification is strongly contingent on South Korea's attitudes toward Japan as well as prospects of stronger ties between the unified Korea and China (Young et al. 2012). The outgroup identity of North Korea and South Korea as holding negative attitudes toward Japan, as well as possible change in the balance of power through strengthened Sino-Korean relations, creates a foundation for concerns among Japanese officials and experts that are reflected in the narrative of "Reunification of Korea will create a threat for Japan." This narrative sees power as coercion and prescribes the development of multiple defensive measures by Japan to protect its position in the region and its image in international relations.

The scenario of a strengthened U.S.-South Korea alliance together with continuous cooperation between the U.S. and Japan raises positive expectations about the unification and creates a ground for its support in Japan. The policy of the U.S. in the region has a strong impact on Japanese position that is linked closely with the objectives of the U.S. (DiFilippo 2018). Some experts already have noticed the emergence of supportive views among Japanese elite (Young et al. 2012). This support is evident in both narratives of "Reunification of Korea will promote reconciliation and democratic processes in Japan" and "Reunification 
of Korea will result in cooperative policies of restorative justice." The former emphasizes the symmetric democratic process based on the ingroup responsibility for colonizing and mobilizing Koreans for the war as well as for the division of Korea, and legitimate power that Japan could gain through the assistance in the unification. The latter underlines a reciprocity of procedures of justice based on an acknowledgement of the responsibility of both the ingroup and the outgroup for suffering of victims, and cooperative power resulting from collaboration between Japan and two Koreas. However, both narratives are rooted in the critical importance of the U.S.'s role in the region, as well as strong ties between Japan and the U.S. in addressing the rise of China.

The perception the international order becomes more interdependent and peace is a crucial condition of international cooperation is also leading to the stronger support of unification. This support is reflected in the narrative of "Reunification of Korea will promote peace in the region." This narrative is rooted in the ingroup identity as a peaceful country that holds a creative power to establish peace in the region.

Second, the Japanese position toward Korean unification heavily depends on Japan's domestic politics (Shigemura 1997). The right-wing politicians, including members of the Liberal Democratic Party, emphasize the outgroup identity of Koreans as holding negative attitudes toward Japan and see the unification as a threat. They also agree with the importance of justice procedures and stress any retributions are contingent on the return of Japanese citizens abducted by North Korea. These attitudes are represented in narratives of "Reunification of Korea will create a threat for Japan" and "Reunification of Korea will result in cooperative policies of restorative justice." Left-wing political leaders, including members of the Social Democratic Party, see Japanese identity through the moral obligation associated with colonial rule and consequent partition, and support ideas of cooperative and productive power resulting in reconciliation and peace. Their positions are reflected in the narratives of "Reunification of Korea will promote peace in the region" and "Reunification of Korea will promote reconciliation and democratic processes in Japan."

Third, several models of unification define possible responses of Japan (Moon and Lee 1999). The model of Unification by Absorption (or German model) is based on the sudden collapse of North Korea and its assimilation into South Korea. It is associated with transitional social, political, and economic instability. In this model, South Korea gains power over all of the Korean peninsula and takes control of all military and nuclear assets of North Korea. The model of Unification by Force (or Vietnamese model) is rooted in violent means used by North Korea. This scenario can lead to the counterattacks by South Korea in alliance with the U.S. and consequent occupation of North Korea by joint 
U.S.-South Korean forces and control over North Korea's nuclear weapons by the U.S., or total denuclearization. The model of Unification by International Trusteeship (or Lebanese model) is rooted in collaborative efforts of external powers to lead the transitional period under international peacekeeping and stabilization operations. In this scenario, the unification will also include denuclearization of Korea. The model of Unification by Consensus is based on agreement between two Koreas. It assumes the continuous division during the process of negotiation. It requires significant economic development of North Korea, arms control, and security and confidence-building measures. While this model is rooted in peaceful co-existence, the possibility of the united Korea with nuclear weapons remains very high.

Concerns about security of Japan and threat from the nuclear united Korea presented in "Reunification of Korea will create a threat for Japan" narrative arrive from the consideration of the model of Unification by Absorption and the model of Unification by Consensus. This narrative emphasizes the possible changes in the balance of power as well as negative attitudes of the outgroup. The possibility of the model of Unification by International Trusteeship also raises concerns among Japanese experts because China can gain considerable control over the united Korea, thus changing the power balance in the region. However, the models of Unification by Consensus and Unification by International Trusteeship can be seen favorable, if Japan plays an important role in the process of unification that is represented in the narratives of "Reunification of Korea will result in cooperative policies of restorative justice," "Reunification of Korea will promote reconciliation and democratic processes in Japan," and "Reunification of Korea will promote peace in the region." In the first narrative, the ingroup identity of Japan as a country responsible for colonizing and mobilizing Koreans for the war, as well as for the division of Korea, gives Japan legitimate power to assist the unification. In the second narrative, acknowledgement of a shared ingroup and outgroup responsibility for suffering of victims develops a foundation for Japan's cooperative power. In the third narrative, the ingroup identity as a peaceful country provides Japan with the creative power to establish peace in the region.

\section{CONCLUSION}

The unification of Korea is not a reality, but rather a possibility, characterized by projections, speculations, and a high level of uncertainty. However, the unification process is actual as leaders in the region take it into consideration while developing their domestic and foreign policies. Thus, the unification of Korea has a great influence over the entire region and Japan in 
particular. It creates the perceived asymmetries in the relative gains of all regional players and thus possible change in the balance of power in the region. It can also impact complex relations of cooperation and competition between China and Japan, the U.S.-Japan alliance, and continuous conflicts in the relationships amongst Japan, North Korea and South Korea.

This research revealed four complex narratives representing Japanese perceptions of Korean unification that are rooted in the interrelations between meanings of social identity and concepts of power. Competing, contrasting, and sometimes overlapping, these narratives create a complex landscape of views on the past, current, and future interrelations between Japan and two Koreas. While they depend on multiple internal and external factors, as shown in the discussion on the perceptions of Korean unification in the literature presented in section III, these competing narratives remain relatively stable within a particular political and social order and impact policy making processes. Despite their differences, all four narratives call for a greater involvement of Japan into the process of Korean unification.

The narrative of "Reunification of Korea will create a threat for Japan" prescribes the development of policies aiming at protecting Japan's interests and security with multiple defensive measures. The vital requirement for the unified Korea is to become a nuclear-weapons-free state and friendly towards Japan. The narrative of "Reunification of Korea will promote reconciliation and democratic processes in Japan" advocates for the promotion of a comprehensive historic analysis of Japanese policies and actions during the occupation of Korea and discussion of its colonial responsibility. This analysis should create a foundation for public policy justifying and promoting Japan's leading role in unification and de-nuclearization of Korea. The narrative of "Reunification of Korea will result in cooperative policies of restorative justice" prescribes broad negotiations between Japan and two Koreas on addressing both wrongdoings of Japanese Imperial Government and the role of Korean elite in the colonization. While compensation to North Korea should be contingent on the return of abducted Japanese citizens, it also could be an excellent opportunity for Japan to profit financially and economically. The narrative of "Reunification of Korea will promote peace in the region" promotes a leading role of Japan as a peaceful country that can inspire and empower two Koreas to bring harmony and reconciliation in the region. Under such a circumstance, policies in Japan should aim at improving relations between Japan and the united Korea.

Most likely, in a continuous situation of uncertainty, the Abe administration will use a minimalist strategy (Nilsson-Wright, 2019). This Japanese engagement would be implemented through an incremental policy to be adopted at each emerging stage of the unification process. Japan would help avoid the 'sadden collapse' of North Korea and encourage North Korea's gradual transformation 
(Okonogi, 1999). Involvement of Japan can vary from economic measures (incentive-driven economic assistance, private investments in special economic zone, structural reforms) and security measures (increasing Japanese military potential, assurance in denuclearization of North Korea) to diplomacy (normalization of relations with North Korea, facilitation of cooperation between two Koreas) and social policies (support of democratization and rule of law, political reforms). This involvement can decrease the level of threat perceptions in Japan and enhance the support for Korean unification among Japanese public.

\section{REFERENCES}

Allen, Amy. 2000. The Power of Feminist Theory: Domination, Resistance, Solidarity. Westview Press.

Arendt, Hannah. 1970. On Violence. Harcourt: Brace \& World.

Armacost, Michael H. and Kenneth B. Pyle, 2001. "Japan and the Unification of Korea: Challenges for U.S. policy coordination." in Korea's Future and the Great Powers edited by Nicholas Eberstadt and Richard J. Ellings, 125-163, Seattle, WA: University of Washington Press.

Arrington, Celeste L. 2018. "The Mutual Constitution of the Abductions and North Korean Human Rights Issues in Japan and Internationally." Pacific Affairs 91(3): 471-497.

Bae, Jung-Ho, Young-Ho Park, Jae-Jeok Park, Dong-Soo Kim and Jang-Ho Kim. 2014. The Perceptions of Northeast Asia's Four States on Korean Unification. Seoul, Korea: Korea Institute for National Unification.

Barnett, Michael and Raymond Duvall. 2005. Power in Global Governance, Cambridge University Press.

Barnett, Michael and Raymond Duvall. 2005. "Power in International Relations." International Organization 59: 39-75.

Barrett, Stanley R. 2002. Culture Meets Power, Westport, CT: Praeger.

Bourdieu, Pierre. 1977. Outline of a Theory of Practice $1^{\text {st }}$ English Ed. Cambridge University Press.

Cartwright, Dorwin. 1959. Studies in Social Power. Research Center for Group Dynamics, Institute for Social Research: University of Michigan.

Dahl, Robert A. 1957. "The Concept of Power." Systems Research and Behavioral Science 2(3): 201-215.

Deutsch, Max and Harold B. Gerard. 1955. "A Study of Normative and Informational Social Influences upon Individual Judgment." Journal of Abnormal Social Psychology 51: 629-636.

DiFilippo, Anthony. 2018. "Cold war Stasis: Past and Continuing Problems in the Normalization.” North Korean Review 14(2): 64-86. 
Festinger, Leon. 1953. “An Analysis of Compliant Behaviour.” In Group Relations at the Crossroads edited by Muzafer Sherif and Milbourne Otto Wilson, 232-256. Harper.

Fiske, Susan T. 1993. "Controlling Other People: The Impact of Power on Stereotyping." American Psychologist 48: 621-628.

Foucault, Michel. 1981. The History of Sexuality. Harmondsworth: Penguin Books.

French, John R.P. and Bertram Raven. (1959) "The Bases of Social Power." in Studies in Social Power edited by Dorwin Cartwright, 150-167. Michigan: University of Michigan, Research Center for Group Dynamics, Institute for Social Research.

Galam, Serge and Serge Moscovici. 1995. "Towards a Theory of Collective Phenomena: III. Conflicts and Forms of Power." European Journal of Social Psychology 25: 217-229.

Gene, Sharp. 1973. The Politics of Nonviolent Action. Boston: P. Sargent Publisher. Glosserman, Brad and Scott A. Snyder. 2015. The Japan- South Korea Identity Clash: East Asian Security and the United States. New York, NY: Columbia University Press.

Grieco, Joseph M. 1990. Cooperation among Nations: Europe, America, and Non-Tariff Barriers to Trade. Ithaca, NY: Cornell University Press.

Gruber, Lloyd. 2000. Ruling the World: Power, Politics, and the Rise of Supranational Institutions. Princeton, NJ: Princeton University Press.

Guillaume, Xavier. 2011. International Relations and Identity: A Dialogical Approach London, UK: Routledge.

Guzzini, Stefano. 2000. "The use and misuse of power analysis in international theory." In Global Political Economy: Contemporary Theories edited by Ronen Palan, 54-67. London: Routledge.

Hagstrom, Linus. 2016. Identity Change and Foreign Policy: Japan and its 'Others' edited. New York: Routledge.

Huh Moon Young, Cha Moon Seok, Jeong Young Tai, Jung Hyun Soo, Kang Gu Sup, Kwon Oh Kook, Kwon Young Kyong, Park Jong Chul, Son Gi Woong and Yeo In Kon. 2012. Basic Reading On Korean Unification. Seoul, Korea: Korean Institute for National Unification.

Hwang, Eui Gak. 2010. The Search for the Unified Korea. London: Springer.

Ikeda, Josuke. 2008. "Japanese Vision of International Society: A Historical Exploration." In Is There A Japanese IR? Seeking an Academic Bridge through Japan's History of International Relations edited by Kosuke Shimizu, Josuke Ikeda, Tomoya Kamino and Shiro Sato, 5-28. Research Series 5, Shiga: Afrasian Centre for Peace and Development Studies, Ryukoku University

Jones, James M. 1972. Prejudice and Racism. Philadelphia: Addison-Wesley. 
Kamikawa, Hikomatsu. 1928/1966. Kokusai Renmei Seisaku Ron (On The League of Nations). Tokyo: Keisou Shobou.

Kelman, Herbert C. 1958. "Compliance, Identification, and Internalization Three Processes of Attitude Change." Journal of Conflict Resolution 2(1): 51-60.

Kim, Ji Young. 2014. "Escaping the Vicious Cycle: Symbolic Politics and History Disputes between South Korea and Japan.” Asian Perspective 38: 31-60.

Kim, Kyuryoon and Jae Jeok Park. 2012. Korean Peninsula Division/Unification:

From the International Perspective. Seoul: Korea Institute for National Unification.

Korostelina, Karina V. 2013. Constructing Narrative of Identity and Power: Self-imagination in a Young Ukrainian Nation. Lexington.

$\mathrm{Ku}$, Yangmo. 2016. "Irreparable Animosity? Centripetal versus Centrifugal Force in South Korea-Japan Mutual Perceptions 1998-2015." Asian Journal of Peacebuilding 4(1): 53-76.

Lee, Chae Jin. 2001. "Conflict and Cooperation: The Pacific Powers and Korea." In Korea's Future and the Great Powers edited by Nicholas Eberstadt and Richard J. Ellings, 51-87. Seattle, WA: National Bureau of Asian Research.

Mann, Michael. 2012. The Sources of Social Power: Volume 4, Globalizations, 1945 -2011. Cambridge: Cambridge University Press.

Michishita, Narushige. 2014. "Changing Security Relationship between Japan and South Korea: Frictions and hopes." Asia-Pacific Review 21(2): 19-32.

Moon, Chung-in and Dong Yoon Lee. 1999. "Korean Unification: contending scenarios and implications for Japan." In Japan and Korean Unification edited by Young Sun Lee and Masao Okonogi, 15-32. Seoul, Korea: Yonsei University Press.

Moscovici, Serge. 1976. Social Influence and Social Change. Academic Press.

Nilsson-Wright, John. 2019. "Nuclear Crisis on the Korean Peninsula: Strategic Adaptation, the Abe Administration and Extended Deterrence in the Face of Uncertainty." Japan Forum 31(1): 110-131.

Nye, Joseph. 2002. The Paradox of American Power: Why the World's Only Superpower Can't Go it Alone. New York: Oxford University Press.

Okonogi, Masao. 1999. "The North Korean Crisis and Japan's Political and Diplomatic Responses." In Japan and Korean Unification edited by Young Sun Lee and Masao Okonogi, 51-66. Seoul, Korea: Yonsei University Press.

Osawa, Akira. 1931. Kokusai-hou Chitsujo Ron (On International Legal Order). Tokyo: Iwanami Shoten.

Park, Hahnkyu. 1988. "Between Caution and Cooperation: South Korea-Japan Security Relationship in the Post-Cold War Period." Korean Journal of 
Defense Analysis 10(1): 95-120.

Patton, Michael Quinn. 2002. Qualitative Research \& Evaluation Methods. Thousand Oaks, CA: Sage Publishing.

Robson, Colin. 2011. Real World Research: A Resource for Users or Social Research Method in Applied Settings. Cornwall, UK: Wiley.

Royama, Masamichi. 1925/1979. Seijigaku no Ninmu to Taishou (The Purpose and Object of Politics). Tokyo: Chuo-Koronsha.

Rozman, Gilbert. 2001. “Japan's Images of China in the 1990s: Are They Ready for China's 'Smile Diplomacy' or Bush's 'Strong Diplomacy'?” Japanese Journal of Political Science 2(1): 97-125.

Sakaedani, Akiko. 2005. "FIFA World Cup and its Effects on the Reconciliation between Japan and the Republic of Korea." Japanese Journal of Political Science, 6(2): 233-257.

Sakamoto, Yoshikazu. 2010. "On Paik Nak- chung's Views Regarding the Unification of Korea: from a Japanese Perspective.” Inter-Asia Cultural Studies 11(4): 531-535.

Samuels, Richard J. 2006. Securing Japan. Ithaca, N.Y.: Cornell University Press. Shigemura, Toshimitsu. 1997. "The Reunification of Korean Peninsula and Japanese Foreign Policy." In The four powers and the Korean Unification Strategies edited by Tae-Hwan Kwak, 49-58. Seoul, Korea: Kyungnam University Press.

Tamaki, Taku. 2010. Deconstructing Japan's Image of South Korea: Identity in Foreign Policy, New York, N.Y.: Palgrave Macmillan.

Tanaka, Hitoshi. 2006. "Japan's Perspective on the Korean Peninsula." East Asia Insights 1: 1-4.

Turner, John C. 2005. "Explaining the Nature of Power: a Three-process Theory." European Journal of Social Psychology 35(1): 1-22.

Weber, Max. 1978. Economy and Society: An Outline of Interpretive Sociology/ University of California Press.

Wirth, Christian. 2015. "Power' and 'Stability' in the China-Japan-South Korea Regional Security Complex." The Pacific Review 28(4): 553-575. 


\section{APPENDIX}

\section{Interview questions}

1. How are history and memory important for national identity in Japan and Korea?

2. How current relationships between North and South Korea and Japan are affected by the history?

3. Why is post-war settlement and reconciliation between both Koreas and Japan still an issue?

4. Do you see the possibility of improving relationships between two Koreas?

5. Will it impact relationship between Japan and Korea?

6. What are possible implications of the unification of Korea for Japan? 
